\title{
Characteristics of Libido and Testosterone Concentration of Polled and Horned Bali Bulls after GnRH Injection
}

\author{
Hasbi $\mathrm{H}^{1^{*}}$, Sonjaya $\mathrm{H}^{1}$, Baco $\mathrm{S}^{1}$, Amalia $\mathrm{R}^{1}$, Gustina $\mathrm{S}^{2}$ \\ ${ }^{I}$ Department of Animal Production, Faculty of Animal Science, Hasanuddin University, \\ Jl. Perintis Kemerdekaan Km.10, Makassar 90245, Indonesia \\ ${ }^{2}$ Department of Animal Science, Faculty of Animal Science and Fisheries, Universitas Sulawesi Barat, \\ Jl. Prof. Dr. Baharuddin Lopa, Tande Timur, Majene, 91412, Indonesia \\ *Corresponding authorE-mail: hasbi_fapetunhas@yahoo.com
}

(received 30-07-2021; revised 04-11-2021; accepted 04-11-2021)

\begin{abstract}
ABSTRAK
Hasbi H, Sonjaya H, Baco S, Amalia R, Gustina S. 2021. Karakteristik libido dan konsentrasi hormon testosteron sapi bali jantan polled dan bertanduk setelah penyuntikan GnRH. JITV 26(3): 108-114. DOI: http://dx.doi.org/10.14334/jitv.v23i4.2851.

Sapi Bali merupakan salah satu plasma nutfah asli Indonesia yang dalam pengembangannya ditemukan jenis tidak bertanduk atau polled. Polled adalah sapi Bali yang tanduknya tidak tumbuh secara alami, namun memiliki karakteristik yang sama dengan yang bertanduk. Akan tetapi ada indikasi bahwa polled memiliki libido yang lebih rendah. Penelitian ini bertujuan untuk melihat bagaimana karakteristik libido dan konsentrasi testosteron setelah penyuntikan gonadotrophin releasing hormone (GnRH). Pada penelitian ini digunakan masing-masing 7 ekor pejantan sapi Bali polled dan bertanduk berumur 3.5-6 tahun. Karakteristik libido diamati dengan mencatat waktu pertama pejantan mencumbu teaser sampai terjadinya ejakulasi sedangkan konsentrasi testosteron diukur menggunakan plasma darah yang diambil pada hari ke-0 atau sebelum penyuntikan, hari ke-7, dan hari ke-14 setelah penyuntikan GnRH. Analisa testosteron menggunakan metode enzyme linked immunosorbent assay (ELISA). Hasil penelitian menunjukkan bahwa libido sapi polled tidak berbeda $(\mathrm{P}>0.05)$ dibandingkan bertanduk baik pada hari ke- 0 , ke- 7 dan ke-14 setelah penyuntikan GnRH. Namun, pada sapi polled hari ke-7 setelah penyuntikan GnRH nyata lebih rendah dibandingkan hari ke-0 dan ke-14, tetapi pada hari ke-0 tidak berbeda dengan hari ke-14. Konsentrasi testosteron pada hari ke-7 setelah penyuntikan GnRH tidak berbeda $(\mathrm{P}>0.05)$ dibandingkan hari ke-0 baik pada pejantan polled maupun bertanduk, tetapi pada hari ke-14 setelah penyuntikan nyata lebih tinggi $(\mathrm{P}<0.05)$ pada pejantan bertanduk dibandingkan polled. Kesimpulan, pejantan sapi Bali polled dan bertanduk memiliki libido tinggi dengan skor +1 , namun pada hari ke-7 setelah penyuntikan GnRH libido pejantan polled lebih rendah dibandingkan bertanduk. Konsentrasi testosteron pejantan polled dan bertanduk pada hari ke7 setelah penyuntikan GnRH tidak berbeda dibandingkan dengan hari ke-0, sedangkan ke-14 lebih tinggi pada pejantan bertanduk.
\end{abstract}

Kata Kunci: GnRH, Bertanduk, Libido, Sapi Bali Polled, Testosteron, GnRH,

\section{ABSTRACT}

Hasbi H, Sonjaya H, Baco S, Amalia R, Gustina S. 2021. Characteristics of libido and testosterone concentration of polled and horned Bali Bulls after GnRH injection. JITV 26(3): 108-114. DOI: http://dx.doi.org/10.14334/jitv.v23i4.2851.

Bali cattle are one of the original Indonesian germplasm, which in its development were found to be hornless or polled. Polled are Balinese cattle whose horns do not grow naturally, but have the same characteristics as those with horns. However, there are indications that polled have a lower libido. The purpose of this study was to determine the characteristics of libido and testosterone concentration after gonadotrophin releasing hormone $(\mathrm{GnRH})$ injection. In this study each of 7 male polled and horned Bali cattle aged 3.5-6 years were used. Libido characteristics were observed by recording the first time the male fondled the teaser until ejaculation, while the testosterone concentration was measured using blood plasma taken on day 0 or before injection, day $7^{\text {th }}$, and day $14^{\text {th }}$ after GnRH injection. Testosterone analysis used enzyme linked immunosorbent assay (ELISA) method. The results showed that the libido of polled was not different $(\mathrm{P}>0.05)$ compared to that of the horned on the $0,7^{\text {th }}$ and $14^{\text {th }}$ days after GnRH injection. However, in polled on the $7^{\text {th }}$ day after GnRH injection, it was significantly lower than on day 0 and 14 , but on day 0 it was not different with day 14. Testosterone concentration on day 7 after injection of GnRH was not different $(\mathrm{P}>0.05)$ compared to day 0 both in polled and horned bulls, but on day 14 after injection was significantly higher $(\mathrm{P}<0.05)$ in horned than polled. In conclusion, polled and horned Bali bulls had high libido with a score of +1 , but on the $7^{\text {th }}$ day after GnRH injection, polled had lower libido than horns. The testosterone concentrations of polled and horned on day 7 after GnRH injection were not different compared to day 0 , while the $14^{\text {th }}$ day was higher in horned bull.

Key Words: GnRH, Horned, Libido, Polled Bali Bulls, Testosterone 


\section{INTRODUCTION}

Bali cattle is one of the Indonesia original germplasms which has great potential to produce breeds with high quality, and to supply the needs of animal protein. Bali cattle have several advantages including good adaptability to an environment and low feed quality, compact body shape, high carcass percentage up to $52-58 \%$, low fat meat, so that making it suitable to be developed as beef cattle. In addition, Bali cattle also have a high fertility rate reaching $83 \%$, without being affected by feed quality (Utomo et al. 2017). During development, in province of South Sulawesi, Bali cattle without horns were found that is known as polled.

Polled Bali cattle have horns but do not grow naturally. Although without horns, polled generally have the same characteristics as horned Bali cattle. Comparison of measurements of body dimensions and production characteristics between polled and horned Bali cattle did not show any difference. The polled character of males does not have a negative effect on the growth. It can be seen in the weight of polled Bali cattle which is relatively same as the weight of horned at the same age (Zulkharnaim et al. 2017). However, in reality in the field, there are indications that male polled Bali cattle have a lower libido than horned (Hasbi et al. 2021), which has an impact on the difficulty of semen collection. This is thought to be related to hormonal imbalances, especially testosterone. Therefore, a strategy is needed to increase libido in male polled Bali cattle. One strategy that can be done is to perform gonadotrophin releasing hormone $(\mathrm{GnRH})$ induction. Based on report by Monaco et al. (2015) that injection of $\mathrm{GnRH}$ at a dose of $100 \mu \mathrm{g}$ might enhance temporarily testosterone levels in camels, and reach a peak 2 to 3 hours after administration.

Gonadotrophin releasing hormone $(\mathrm{GnRH})$ is a hormone that is often used to increase reproductive capacity in male and female animals (Franssen et al. 2021). GnRH is secreted to stimulate the release of gonadotrophins and testosterone which are important in the process of spermatogenesis, and also sexual behavior (Kowalczyk et al. 2021). GnRH is a hormone originating from the hypothalamus that stimulates the secretion of Follicle Stimulating Hormone (FSH) and Luteinizing Hormone (LH) from the Anterior Pituitary (Khazeni \& Varamini 2018). FSH and LH are the main hormones that control germ cell development (Ramaswamy \& Weinbauer 2014; Rougier et al. 2019). FSH plays a role in controlling the development of germ cells, and together with LH also plays a role in stimulating the expression of androgen receptors and controlling proliferation and maintaining Sertoli cell function (Aksglaede et al. 2011: Kuiri-Hänninen et al. 2011). Furthermore Kuiri-Hänninen et al. (2011) explained that FSH is a hormone that control the proliferation of Sertoli cells which has an impact on the increase in testicular volume. Meanwhile, LH plays a role in controlling germ cell development and stimulating Leydig cells to produce testosterone (Hasbi \& Gustina 2018).

The testosterone plays a role in the initiation, maintenance and restoration of the process of spermatogenesis. Testosterone is synthesized by testicular Leydig cells in response to LH stimulation and plays an important role in maintaining the process of spermatogenesis (Smith \& Walker 2014). Level of testosterone is not only responsible for the condition of bull libido, but also for the volume of ejaculation (Monaco et al. 2015). Decreased testosterone concentrations can cause decreased libido, spermatogenesis, and seminiferous tubule diameter. When testosterone levels are high or low (below the normal threshold) it will result in negative feedback to the hypothalamus which results in disrupted spermatogenesis processes. Otherwise, if testosterone levels are normal, it will stimulate the testicles to carry out the process of spermatogenesis (Keefe et al. 2021).

\section{MATERIALS DAN METHODS}

\section{Materials}

The materials used were 7 bulls polled and 7 horned Bali cattle aged 3.5 to 6 years, 1 Bali anestrus cow as teaser, GnRH (Fertagyl ${ }^{\mathrm{TM}}$, Intervet International B.V.,Boxmeer, The Netherlands), and DRG EIA 1559 Kit (DRG Instruments GmbH, Germany).

\section{Methods}

\section{GnRH Treatment}

Bulls were injected intramuscularly with a single dose of GnRH at a level of $500 \mu \mathrm{g}\left(\right.$ Fertagyl $^{\mathrm{TM}}$, Intervet International B.V., Boxmeer, The Netherlands).

\section{Characteristics of Libido}

Observation of libido characteristics was assessed from a score of -2 to +2 . A score of -2 is indicated by the male not responding to climbing, a score of -1 trying to climb but slipping, a score of 0 starting to actively climb, a score of +1 is reaction of attraction to mating and actively climbing by doing one ejaculation, and a score of +2 is reaction of attraction to mating and actively climb by doing more than one ejaculation (Modification of Menegassi et al. 2011; Perumal et al. 2020). 


\section{Blood Sampling}

These samples were obtained from the jugular vein by damming it in the distal $1 / 3$ of the neck. After the blood is blocked, the area is wiped with a cotton swab moistened with alcohol, and then a sterile needle is inserted at an angle of $30^{\circ}$ upward into the vein with the needle hole facing upwards. The blood collected using a vacuum tube containing $\pm 3 \mathrm{ml}$ ethylene diamine tetraacetic acid (EDTA) 5\%. Technique of blood plasma separation is done by centrifuging at $2000 \mathrm{rpm}$ for 10 minutes until it separates into 3 layers, plasma, buffy coat, and blood cells. The results of the centrifugation (blood plasma) were collected in a microtube and stored at $-20{ }^{\circ} \mathrm{C}$ (until hormone analysis was performed). Parameters were measured by the enzyme linked immunosorbent assay (ELISA) method using the DRG EIA 1559 Kit (DRG Instruments $\mathrm{GmbH}$, Germany). Blood samples were taken 3 times, as shown in Figure 1.

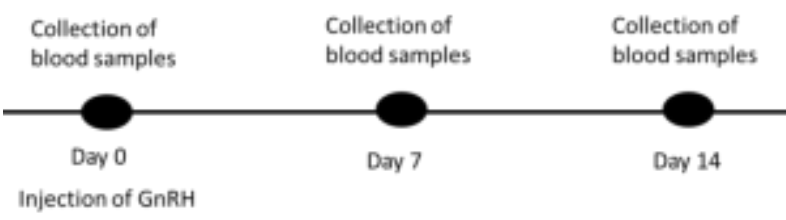

Figure 1. Time of Blood Samples Collection

\section{Data Analysis}

The obtained data were analyzed by a comparative test, namely statistical analysis of the t-test (Independent sample t-test), to compare the sample of polled with horned Bali cattle.

\section{RESULTS AND DISCUSSION}

\section{Libido Characteristics of Polled and Horned Bali Cattle}

Libido is a male's desire to mate which is shown in the form of sexual behavior caused by stimulation (Sam et al. 2017). Libido is one aspect of reproductive function that needs attention. A male's fertility rate and quality of semen will decrease if it is not followed by adequate libido (Kumar et al. 2011). Libido is an expression of engodenous control, especially related to LH or testosterone levels in the blood, as well as stimulation of exogenous through physiological processes and also reproduction experience (Mondal et al. 2019). Libido of a male can be assessed ranging from no response to climbing the teaser to actively climbing by making more than one ejaculation (Menegassi et al. 2011). Meanwhile, according to
Waheeb et al. (2018) that the libido index is measured during the semen collection process based on the level of sexual interest for 10 minutes, while the reaction time related time required for bull recognition of the teaser and the completion of copulation in the artificial vagina. The libido characteristics of polled and horned Bali cattle were presented in Figure 2.

Characteristics of libido indicated by the time it took a male to climb the teaser and ejaculate normally. The results of this study (Figure 2) showed that the libido characteristic in polled Bali cattle were not significantly different $(\mathrm{P}>0.05)$ compared to horned on day 0 or before the GnRH injection, day 7 and 14 after the injection. This finding showed that libido was not affected by the presence or absence of horns in a male. However, on days 0,7 , and 14 showed a tendency to have a higher libido in horned Bali bull. Previous research explained that the libido of polled Bali bull was significantly lower than that of horned (Hasbi et al. 2021). Libido of a male can be influenced by several factors, which are breeds and genetics, age, social relations between males, sexual experience, and climate or environment, stress (Petherick 2005).

Libido is the reaction of a male to climb a female or teaser after being stimulated. Libido can be measured by looking at the time required by a male from being brought near to a female or teaser until false mounting (Salim 2017; Gibson et al. 2020). The results of this study indicated that polled and horned Bali bulls have a high libido with a score of +1 , which is the reaction of interest in mating and actively climbing by doing one ejaculation, although it takes a long time $11.18 \pm 2.02$ to $18.42 \pm 5.57$ minutes starting from approaching the teaser until the first ejaculation occurred in polled bull and $8.15 \pm 3.08$ to $12.33 \pm 3.39$ minutes in horned. Singh et al. (2009) and Kumar et al. (2011)measure level of bulls libido at the semen collection time based on the basis of reaction time, and categorize good libido with reaction time less than $15 \mathrm{~min}$. Meanwhile, Monaco et al. (2015) reported that the average service time required for dromedary camels is $8.2 \mathrm{~min}$.

The results of this study showed that the libido of polled Bali cattle on the 7th day after GnRH injection was significantly lower $(\mathrm{P}<0.05)$ compared to day 0 or before injection and day 14 after injection, while on day 0 it was not different from day 14 (Figure 2). These results indicated that $\mathrm{GnRH}$ injection after day 7 affected libido in male polled Bali cattle, whereas horned Bali cattle had no effect. It indicates that the polled Bali males in this study were more susceptible to stress caused by pain that occurred after GnRH injection treatment. Lieberman et al. (2013) reported that pain sends signals to the hypothalamus. The hypothalamus secretes GnRH which stimulates the anterior pituitary gland to secrete $\mathrm{LH}$, then $\mathrm{LH}$ stimulates Leydig cells and produces testosterone. 




Figure 2. Libido Characteristics of Polled and Horned Bali Cattle after Injection of Gonadotropin Releasing Hormone (GnRH)

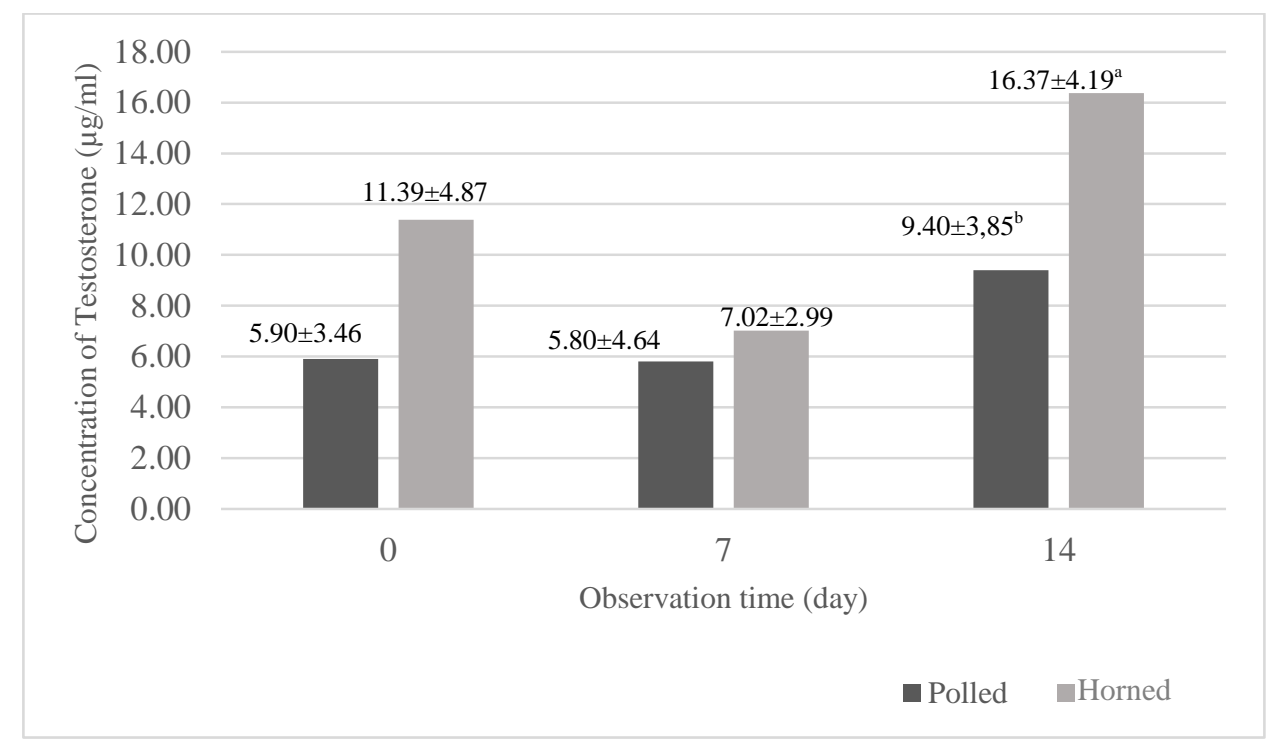

Figure 3. Concentration of the Testosterone in Polled and Horned Bali Cattle after Injection of Gonadotropin Releasing Hormone (GnRH)

Testosterone provides negative feedback to the hypothalamus to inhibit GnRH thereby limiting the rate of testosterone formation. Testosterone is a hormone involved with sexual desire (libido) which provides a sexual stimulus to encourage sexual activity, especially in male animals (Monaco et al. 2015).

\section{Concentration of the Testosterone in Polled and Horned Bali Cattle}

Gonadotropin releasing hormone $(\mathrm{GnRH})$ is a hypothalamic neuropeptide that controls the reproductive endocrine system and is thought to be the end product of the central nervous system activator of fertility in all mammals. GnRH initiates the pituitary gland to release the gonadotropins leading to the production of gonadal sex steroids (Salehi et al. 2019).

Injection of GnRH can improve sexual behavior and optimize the quality of spermatozoa (Monaco et al. 2015; Wanlu et al. 2021) through the hormonal cycle. Testosterone is the main androgen in the circulatory system in male animals and is a hormone that affects the level of libido (sexual desire) and provides stimulation for male sexual activity (Rastrelli et al. 2018). The concentration of the hormone testosterone in polled and horned Bali cattle were presented in Figure 3. 
Results of the diversity analysis (Figure 3) showed that on the 7th day after GnRH injection, there was no significant difference $(\mathrm{P}>0.05)$ in the concentration of the testosterone compared to day 0 or before injection in both polled and horned Bali bulls. Whereas on day $\mathrm{e}$ 14th after injection, the testosterone concentration of horned Bali bulls was significantly higher $(\mathrm{P}<0.05)$ compared to polled bulls. This result indicated that polled and horned Bali cattle on day 7 after GnRH injection gave the same response, while on day 14 horned Bali cattle gave a high response to $\mathrm{GnRH}$ injection. However, the results of this study showed the same pattern between polled and horned Bali bulls, the concentration of testosterone decreased on the 7 th day and increased on the 14th day after injection. The concentration of testosterone in polled Bali bulls in this study was $5.90 \pm 3.46-9.40 \pm 3.85 \mathrm{ng} / \mathrm{ml}$ and in horned bulls was $7.02 \pm 2.99-16.37 \pm 4.19 \mathrm{ng} / \mathrm{ml}$. The concentration of testosterone in polled is not much different from previous research conducted by Barret et al. (2012) that testosterone concentration in adult cattle ranges from 3-10 ng/ml, while in horned Bali bulls is higher. In dromedary camels, the basal testosterone level is about $3.0 \mathrm{ng} / \mathrm{ml}$ (Monaco et al. 2015). In zebu males, the average basal concentration of testosterone is $3.27 \mathrm{ng} / \mathrm{ml}$ which are classified as low libido, while normal libido can reach $20 \mathrm{ng} / \mathrm{ml}$ (Mondal et al. 2019), in bulls $9.4 \mathrm{ng} / \mathrm{ml}$ (Kowalczyk et al. 2021), in holstein bulls $7.7 \mathrm{ng} / \mathrm{ml}$ (Devkota et al. 2011).

Hormone concentrations are closely related to external factors that can trigger an increase in testosterone concentrations such as the environment. High or low concentration of hormones are caused by sensory stimuli such as light (eyes), sound (ears), smell (nose), physical stimulation (hot and cold), livestock activity, stress (Duszka et al. 2020; Kırgezen et al. 2021), also testosterone increases in conditions of desire of mating (Rastrelli et al. 2018).

The decrease in testosterone concentration on the 7 th day after GnRH injection in this study was thought to be caused by pain and stress due to the injection, which could last a few days after the injection. This condition would improve on the 14th day after the injection so that the testosterone concentration increased again. Lieberman et al. (2013) reported that pain sends signals to the hypothalamus. The hypothalamus secretes $\mathrm{GnRH}$ which stimulates the anterior pituitary gland to secrete LH. LH stimulates Leydig cells and produces the hormone testosterone, which provides negative feedback to the hypothalamus to inhibit GnRH thereby limiting the rate of testosterone formation. Furthermore, Rastrelli et al. (2018) reported that fluctuations in testosterone levels indicate that testes functionate normally and has a certain pattern that occurs consistently, and is also an indication of testicular activity and the formation of spermatogenesis.
The testosterone hormone in males is closely related to libido in livestock. The hypothalamus will produce $\mathrm{GnRH}$ and parathyroid hormone (PTH) which function to regulate testosterone production and regulate calcium and phosphorus content in the bone including horn. Decreased testosterone will affect parathyroid hormone. Parathyroid hormone, a hormone that has function to regulate calcium and phosphorus content (Levine et al. 2014) while testosterone affects libido levels (Rastrelli et al. 2018).

The results of this study indicated that polled character in Bali cattle do not affect libido, meaning that during the breeding season LH continues to stimulate Leydig cells to produce testosterone even though in small amounts. Apart from internal factors, this condition is also influenced by external factors such as body size and nutrition. Furthermore, Menegassi et al. (2011) reported that the sexual behavior of bulls is influenced by several factors including genetics, environment, nutrition, hormones, sensory acuity, age and experience.

\section{CONCLUSION}

Polled and horned Bali cattle bulls have high libido with a score of +1 , which is the reaction of interest in mating and actively climbing the teaser by doing one ejaculation. However, on the day 7 after GnRH injection, the libido of polled Bali cattle is lower than horned. The concentration of testosterone in polled and horned Bali cattle on the day 7 after GnRH injection was not different compared to day 0 , while it was higher in horned Bali cattle on the day 14 after injection.

\section{ACKNOWLEDGEMENT}

This research is part of research activities funded by the Ministry of Research and Technology/National Research and Innovation AgencyEducation Fund Management Agency (LPDP) with contract number 46/E1/PRN/2020 dated July 1, 2020.

\section{REFERENCES}

Aksglaede L, Christiansen P, Sørensen K, Boas M, Linneberg A, Main KM, Andersson A-M, Skakkebaek NE, Juul A. 2011. Serum concentrations of Anti-Müllerian Hormone (AMH) in 95 patients with Klinefelter syndrome with or without cryptorchidism. Acta Paediatr. 100:839-845. DOI: 0.1111/j.1651-2227.2011.02148.x.

Barret KE, Barman SM, Boitano S, Brooks HL. 2012. Ganong's Review of Medical Physiology 24th Edition's Review of Medical Physiology. New York (USA). 
Devkota B, Takahashi K-I, Matsuzaki S, Matsui M, Miyamoto A, Yamagishi N, Osawa T, Hashizume T, Izaike Y, Miyake Y-I. 2011. Basal levels and GnRHinduced responses of peripheral testosterone and estrogen in Holstein bulls with poor semen quality. J Reprod Dev. 57:373-378.

Duszka K, Gregor A, Reichel MW, Baierl A, Fahrngruber C, König J. 2020. Visual stimulation with food pictures in the regulation of hunger hormones and nutrient deposition, a potential contributor to the obesity crisis.Gao Z, editor. PLoS One. 15:e0232099. DOI: 10.1371/journal.pone.0232099.

Franssen D, Barroso A, Ruiz-Pino F, Vázquez MJ, GarcíaGaliano D, Castellano JM, Onieva R, Ruiz-Cruz M, Poutanen M, Gaytán F, et al. 2021. AMP-activated protein kinase (AMPK) signaling in GnRH neurons links energy status and reproduction. Metabolism. 115:154460.

Gibson MJ, Lawrence KE, Hickson RE, How R, Gedye KR, Jones G, Hoogenboom A, Draganova I, Smith SL, Pomroy WE. 2020. Effects of Theileria orientalis Ikeda type infection on libido and semen quality of bulls. Anim Reprod Sci. 214:106312.

Hasbi H, Gustina S. 2018. Androgen regulation in spermatogenesis to increase male fertility. Indones Bull Anim Vet Sci. 28:13.

Hasbi H, Prahesti KI, Sonjaya H, Baco S, Wildayanti W, Gustina S. 2021. Characteristics of libido and testosterone concentrations of Bali polled and horned Bulls. IOP Conf Ser Earth Environ Sci. 788:012141. DOI: $10.1088 / 1755-1315 / 788 / 1 / 012141$.

Keefe DT, Blais A-S, Rickard M, Yehia N, Chami R, Lorenzo AJ. 2021. Spermatogenesis in pre-pubertal boys with Leydig cell neoplasms suggests paracrine stimulation by testosterone. J Pediatr Urol. 17:48.e1-48.e6.

Khazeni S, Varamini P. 2018. Gonadotropin Releasing Hormone. In: Ref Modul Biomed Sci. Amsterdam (ND): Elsevier.

Kırgezen T, Yücetaş U, Server EA, Övünç O, Yiğit Ö. 2021. Possible effects of low testosterone levels on olfactory function in males. Braz J Otorhinolaryngol. 87:702710 .

Kowalczyk A, Gałęska E, Czerniawska-Piątkowska E, Szul A, Hebda L. 2021. The impact of regular sperm donation on bulls' seminal plasma hormonal profile and phantom response. Sci Rep. 11:11116.

Kuiri-Hänninen T, Seuri R, Tyrväinen E, Turpeinen U, Hämäläinen E, Stenman U-H, Dunkel L, Sankilampi U. 2011. Increased activity of the hypothalamic-pituitarytesticular axis in infancy results in increased androgen action in premature boys. J Clin Endocrinol Metab. 96:98-105. DOI:10.1210/jc.2010-1359.

Kumar A, Singh J, Dadarwal D. 2011. Effect of GnRH treatment in argumentation of libido in relation to plasma androgens, thyroid hormones and biochemical profiles in poor libido breeding bulls. Indian J Anim Sci. 82:831-833.

Levine BS, Rodríguez M, Felsenfeld AJ. 2014. Serum calcium and bone: Effect of PTH, phosphate, vitamin D and uremia. Nefrologia. 34:545-692.

Lieberman M, Marks A, Peet A. 2013. Marks' basic medical biochemistry: a clinical approach. $4^{\text {th }}$ ed. Philadelphia (US): Lippincott Williams \& Wilkins.

Menegassi S, Barcellos J, Peripolli V, Camargo C. 2011. Behavioral assessment during breeding soundness evaluation of beef bulls in Rio Grande do Sul. Anim Reprod. 8:77-80.

Monaco D, Fatnassi M, Padalino B, Aubé L, Khorchani T, Hammadi M, Lacalandra GM. 2015. Effects of a GnRH administration on testosterone profile, libido and semen parameters of dromedary camel bulls. Res Vet Sci. 102:212-216.

Mondal S, Bhakat M, Singh A, Mohanty TK, Abdullah M. 2019. Libido Problem is Untraceable Through Testosterone and Luteinizing Hormone Rhythm in Zebu Breeding Bulls. J Anim Heal Prod. 7:81-84.

Perumal P, Chang S, De AK, Baruah KK, Khate K, Vupru K, Mitra A. 2020. Slow release exogenous melatonin modulates scrotal circumference and testicular parameters, libido, endocrinological profiles and antioxidant and oxidative stress profiles in mithun. Theriogenology. 154:1-10.

Petherick JC. 2005. A review of some factors affecting the expression of libido in beef cattle, and individual bull and herd fertility. Appl Anim Behav Sci. 90:185-205.

Ramaswamy S, Weinbauer GF. 2014. Endocrine control of spermatogenesis: Role of FSH and LH/ testosterone. Spermatogenesis. 4:e996025. DOI/10.1080/21565562.2014.996025.

Rastrelli G, Corona G, Maggi M. 2018. Testosterone and sexual function in men. Maturitas. 112:46-52.

Rougier C, Hieronimus S, Panaïa-Ferrari P, Lahlou N, Paris F, Fenichel P. 2019. Isolated follicle-stimulating hormone (FSH) deficiency in two infertile men without FSH $\beta$ gene mutation: Case report and literature review. Ann Endocrinol (Paris) [. 80:234-239.

Salehi MS, Khazali H, Mahmoudi F, Janahmadi M. 2019. The effects of supraphysiological levels of testosterone on neural networks upstream of gonadotropin-releasing hormone neurons. IJBMS. 22:1066-1072.

Salim MA. 2017. Evaluasi tingkah laku sexual kambing kacang jantan di Unit Pemukiman Transmigrasi (UPT) Desa Bina Gara Kabupaten Halmahera Timur. J Agripet. 17:7-14.

Sam AF, Pudjihastuti E, Hendrik M, Ngangi L, Raka I. 2017. Penampilan tingkah laku seksual sapi pejantan Limousin dan Simmental di balai Inseminasi Buatan Lembang. ZOOTEC. 37:276.

Singh J, Kumar A, Honparkhe M, Dadarwal D, Dhaliwal GS. 2009. Effect of gnrh therapy on plasma steroids, thyroid 
hormones and libido in breeding bulls. Indian Vet $\mathrm{J}$. 86:584-585.

Smith LB, Walker WH. 2014. The regulation of spermatogenesis by androgens. Semin Cell Dev Biol. 30:2-13.

Utomo WT, Suarsana IN, Suartini IGAA. 2017. Karakteristik protein plasma Sapi Bali (Characteristics of Bali cattle plasma proteins). J Vet. 18:232-238.

Waheeb RS, Ashry M, Ali ABA, A. Amrawi G. 2018. Effects of oral administration of gonadotrophin stimulant
(Theriogon ${ }^{\circledR}$ ) on sexual behavior and semen characteristics in Bulls. Asian J Anim Vet Adv. 13:218225 .

Wanlu M, Jiangfeng M, Min N, Xi W, Junjie Z, Zhaoxiang L, Bingqing Y, Shuyu X, Ming H, Yinjie G, et al. 2021. Gonadotropin therapy once a eeek for spermatogenesis in hypogonadotropic hypogonadism. Endocr Pract. 27:1119-1127.

Zulkharnaim, Baco S, Yusuf M, Rahim L. 2017. Comparison of body dimension of Bali polled and horned cattle in South Sulawesi. IJSBAR. 36:133-139. 